\title{
LANDSCAPE DIVERSITY, TYPES AND HOTSPOTS OF SLOVENIA
}

\author{
DOI: http://dx.doi.org/10.18509/GBP.2016.03
}

UDC: 911.52(497.4)

\author{
Dr. Drago Perko \\ Dr. Rok Ciglič \\ Dr. Matija Zorn
}

Anton Melik Geographical Institute Research Centre of the Slovenian Academy of Sciences and Arts, Slovenia

\begin{abstract}
Due to its position at the intersection of the Mediterranean, Alps, Dinaric Alps, and Pannonian Basin, Slovenia is considered one of the most diverse countries in Europe. Based on digital data on relief, rock, and vegetation-the most significant elements of the internal structure of Slovenian landscapes and at the same time of their external appearance-a geographic information system was used to determine the natural landscape diversity and landscape hotspots of Slovenia and its municipalities. Landscape hotspots are defined as areas with the highest landscape diversity, which offers some advantages as well as some disadvantages and challenges to certain municipalities.
\end{abstract}

Keywords: geography, landscape diversity, landscape hotspot, municipality, Slovenia

\section{INTRODUCTION}

Because of Slovenia's location at the intersection of the Mediterranean, Alps, Dinaric Alps, and Pannonian Basin [1], landscape diversity can be regarded as one of the country's natural resources. Diversity can be viewed as a development opportunity on the one hand, but on the other it may create specific challenges for spatial planning. Municipalities with greater landscape diversity and many landscape hotspots can accelerate their economic development because of their attractiveness for tourism or the availability of various natural resources. However, high diversity can also limit the space available for various economic activities, prevent large-scale agricultural production, increase the risk of various natural disasters, and prevent the transfer of good practices from one area to another.

This article analyzes the natural heterogeneity of Slovenia and presents some of the first results of the research project Landscape Diversity and Hotspots of Slovenia. The main goal of this project is to define areas with a similar level of heterogeneity, which is reflected in landscape diversity, and to locate the landscape hotspots of Slovenia as the areas with the highest landscape diversity using a relatively objective method.

Based on descriptions by various authors [2], [3], [4], [5], [6], it is possible to divide the analysis of landscape diversity in the following manner. Diversity or heterogeneity of landscape can be analyzed using categorical and/or numerical data. Complexity refers to a qualitative or categorical description and variability refers to a quantitative or numerical description of a landscape. Complexity (also termed structure) consists of composition (also termed diversity, landscape diversity, or richness) and configuration (also termed pattern or spatial configuration). 
Composition provides information about the number and percentage of certain categories or types (in the case at hand, relief types, rock types, vegetation types, landscape types, etc.). Configuration deals with the spatial arrangement of categories or types.

In addition to complexity or structure, there are two additional parts of diversity or heterogeneity of landscape: function and dynamics (which consists of complexity and function).

This article deals with landscape diversity (i.e., composition) based on three natural elements (relief, rocks, and vegetation). This means that we analyzed the number of different elements in certain area.

\section{METHODOLOGY}

Using a geographical information system, we first calculated the diversity of relief types, rock types, and potential vegetation types, and then we determined their average diversity (referred to as landscape diversity), and in the end we selected landscape hotspots (the areas with the greatest landscape diversity) and landscape coldspots (the areas with the least landscape diversity).

Our primary database included three typologies [7]: relief typology with seven types (simplified from eight original categories), rock typology with fifteen types (simplified from 186 original categories), and vegetation typology with fifteen types (simplified from the original sixty-two categories).

All of the classifications were transformed from vector format to raster format because the remainder of the study used geoinformation tools for processing raster data layers. A $25 \mathrm{~m}$ resolution was used for rasterization. The final raster provides $32,436,693$ square cells with a baseline of $25 \mathrm{~m}$ and an area of 6.25 ares [8].

After preparing the data layers, the number of types appearing in a $1 \mathrm{~km}$ radius was calculated for each cell (Figure 1 shows the basic logic of the method with a simple example). The radius was defined by trial and error. It is obvious that a smaller radius would yield similar results, but landscape diversity would be limited to a smaller area, and a larger radius would yield landscape diversity only for larger areas. In this way, a diversity map was obtained for each of the three typologies.
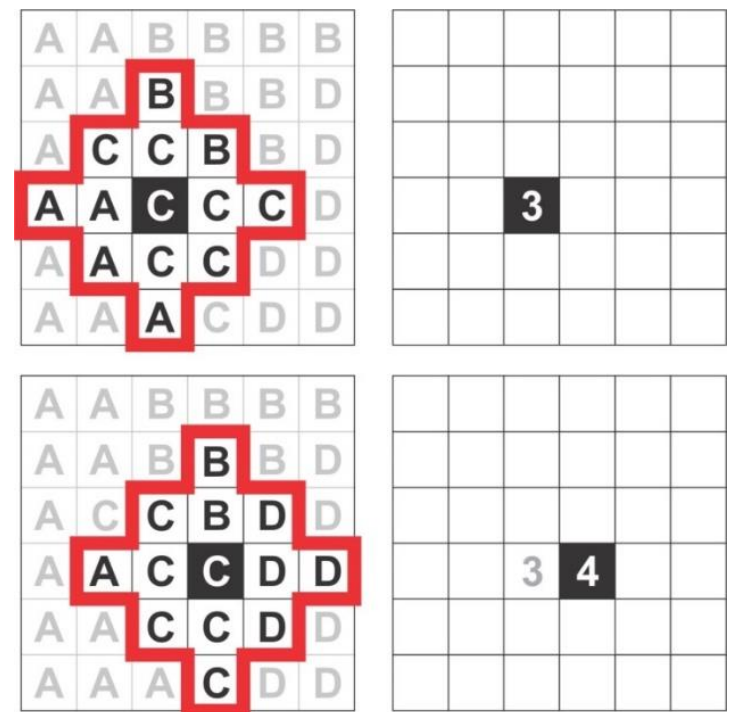

Figure 1. Calculation of various unique values (types or categories) around the cell [1]. 
After creating the diversity layer for each typology analyzed, all of them were joined into a landscape diversity layer. This was done in a way that diversity layers according to relief, rocks, and vegetation were divided by the number of all possible types (seven relief types, fifteen rock types, and fifteen vegetation types). This therefore shows the share of all types presented in Slovenia in a radius of $1 \mathrm{~km}$ for each cell within a specific classification. Then all of the weighted diversity layers were used to calculate an average, which is also the final result: the landscape diversity layer (Figure 2) with a landscape diversity coefficient (values between 0 and 1). On this basis we defined landscape hotspots and landscape coldspots in Slovenia (Figure 3).

\section{LANDSCAPE HOTSPOTS AND COLDSPOTS OF SLOVENIA}

The map showing the landscape diversity of Slovenia (Figure 2) highlights areas (i.e., municipalities) that have higher variety of natural phenomena and processes. The most diverse areas lie along the contacts of major relief forms (between plains, valleys, hills, and mountains), which are often related to changes in lithology and vegetation. Such contacts are usually also the major borders for geomorphological and other natural processes.

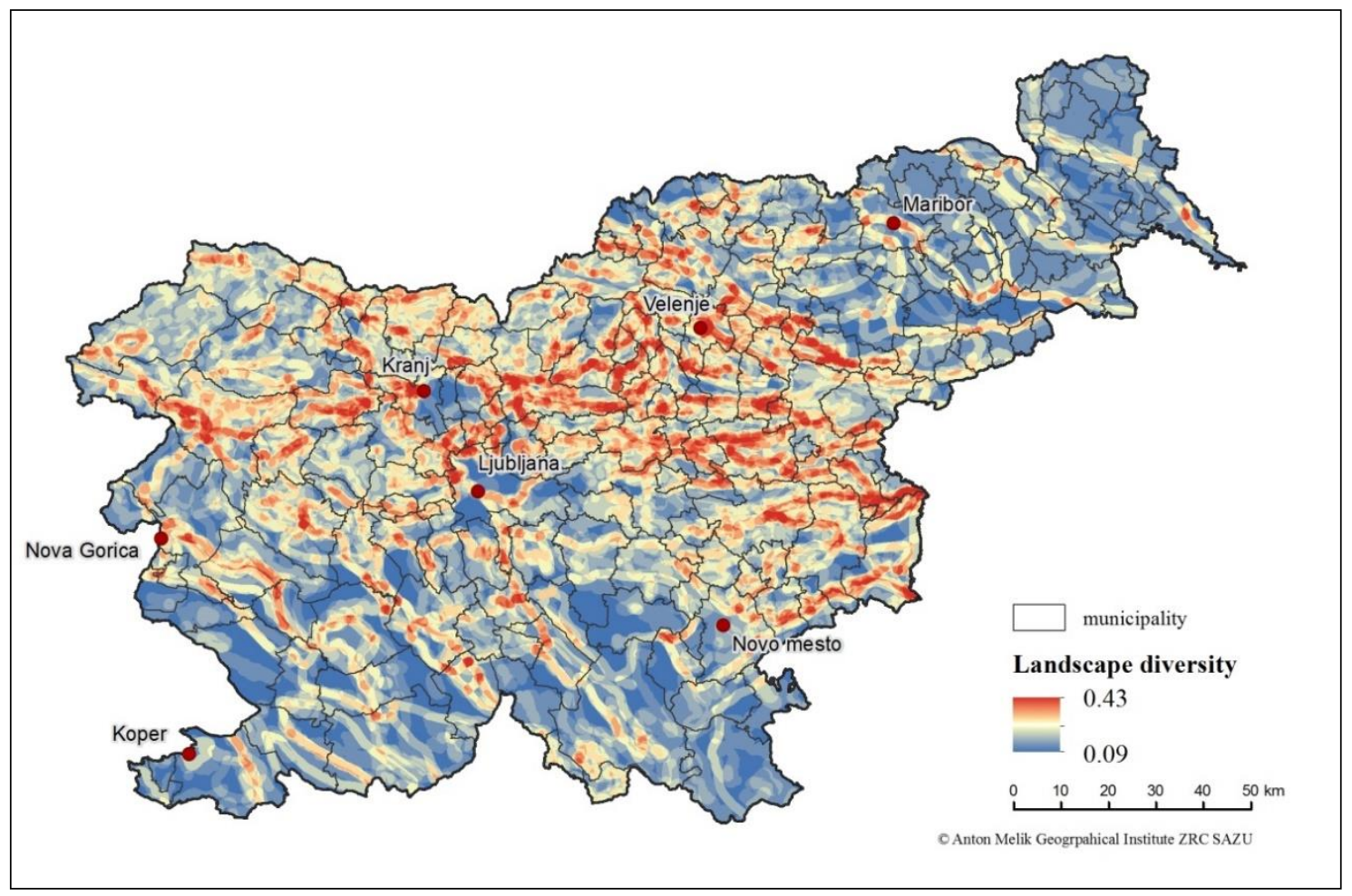

Figure 2. Landscape diversity and municipal borders.

The minimum value of the landscape diversity coefficient in Slovenia is 0.0921. These areas can be regarded as coldspots (Figure 3) and cover $8.9 \%$ of Slovenia. They are frequent in Dinaric plateaus, Dinaric plains, and Pannonian plains. Dinaric landscapes are unified; a typical landscape consists of carbonate rocks (limestone or dolomite), beech and fir forests, and few surface watercourses, and are formed of plateaus. Pannonian plains are flat plains with minimum relief roughness; the typical bedrock is non-carbonate 
sediments. Pannonian plains are much more settled than Dinaric plateaus, thus forest cover is sparse, but potential vegetation is forest of beech, chestnut, and oak.

With $8.9 \%$ of Slovenia regarded as coldspots, the same percentage of the most diverse areas in Slovenia can be defined as hotspots. According to frequency distribution, we selected $8.3 \%$ of areas with the highest values (Figure 3).

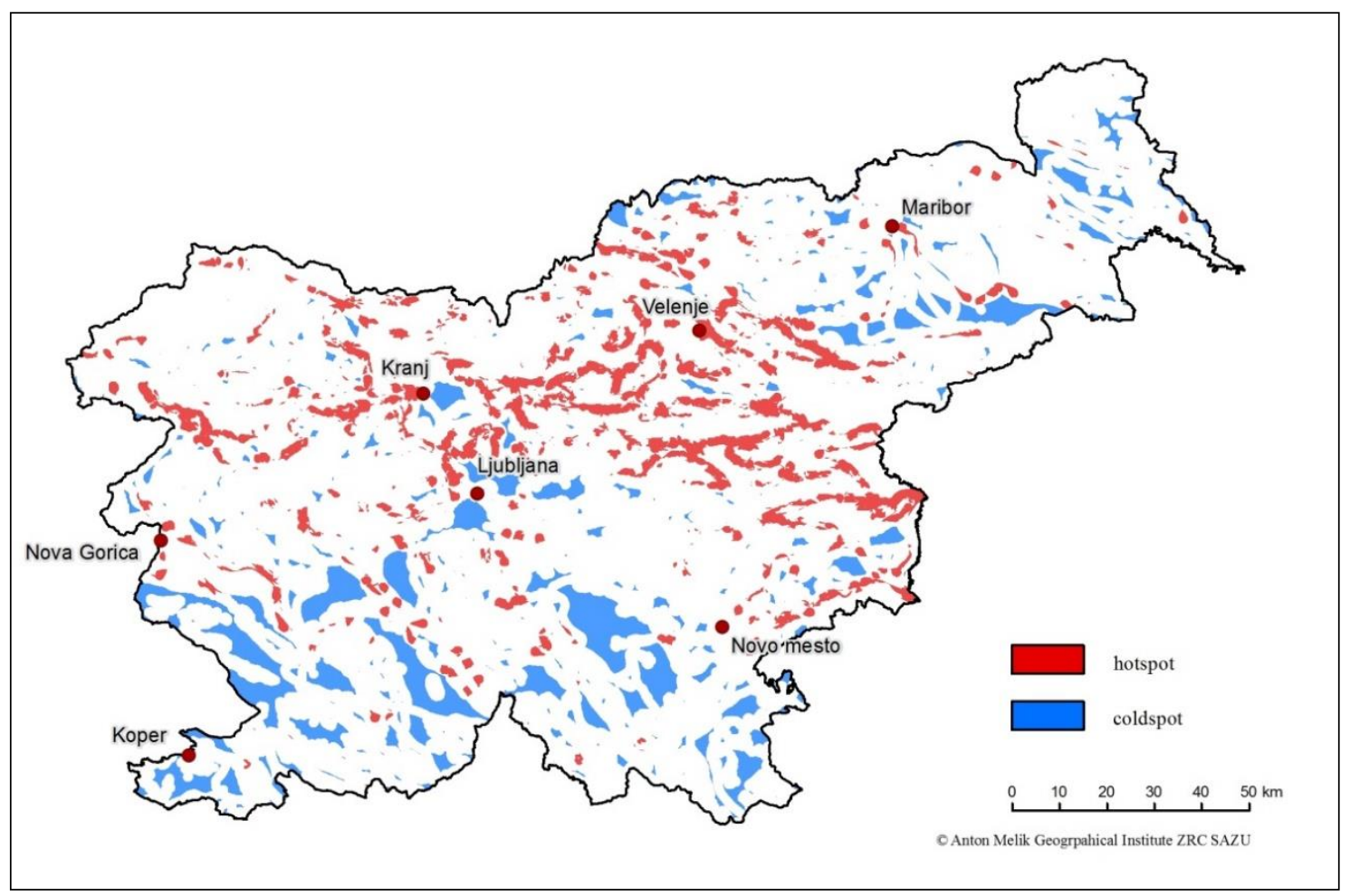

Figure 3. Landscape hotspots (red) and coldspots (blue) in Slovenia.

\section{LANDSCAPE DIVERSITY OF SLOVENIAN MUNICIPALITIES}

Municipalities in Slovenia are local administrative units at the second level (LAU 2 level; the first level is the state level) and are thus important spatial units for planning and development. The landscape diversity layer of Slovenia also makes it possible to assess diversity at the municipality level (Figure 2). Such information offers some additional overview over their natural characteristics. Thus we also analyzed the value of diversity for all Slovenian municipalities. The analysis was performed separately within each natural landscape type (Table 1).

The natural landscape typology of Slovenia from 1998 [9] includes nine landscape types:

- Alpine mountains,

- Alpine hills,

- Alpine plains,

- Pannonian hills,

- Pannonian plains,

- Dinaric plateaus,

- Dinaric plains,

- Mediterranean hills,

- Mediterranean plateaus. 
The average landscape diversity coefficient of Slovenia is 0.1624. Above-average diversity characterizes all three Alpine landscape types. The maximum landscape diversity coefficient of 0.1836 is found in the Alpine mountains, and the minimum of 0.1292 in the Mediterranean plateaus.

Of the 211 municipalities, more than one-third lie entirely within only one landscape type, less than half in two, slightly over one-tenth in three, and only five municipalities in four landscape types.

Slovenia's high landscape diversity occurs where different landscape types meet, and therefore it is logical that municipalities located in several landscape types have a higher landscape diversity coefficient (in terms of rock, vegetation, and relief) than municipalities that lie in only one. Municipalities located entirely in one of the landscape types have an average landscape diversity coefficient of 0.1563 , municipalities in two types 0.1653 , and municipalities in three types 0.1711 .

Among all the municipalities, the Alpine Municipality of Nazarje in northern Slovenia has the maximum landscape diversity coefficient, at 0.2419 , whereas the Pannonian Municipality of Markovci in northeastern Slovenia has the smallest one, at 0.1045. The difference is more than twofold.

The five most diverse municipalities with many landscape hotspots are Nazarje, Štore, Mozirje, Vransko, and Velenje. They are located in the northeastern part of central Slovenia, where Alpine mountains meet Alpine hills and Alpine plains. High differences in elevation and differences in lithology also cause differences for growth conditions for vegetation. Thus it is not surprising that these parts of Slovenia are regarded as hotspots. The least diverse are the municipalities of Markovci, Izola, Kidričevo, Beltinci, Veržej, and Žužemberk. Markovci, Kidričevo, Beltinci, and Veržej are located in the Pannonian plains, which (as already mentioned) are less diverse. The Municipality of Izola is a small municipality along the narrow coastal belt and thus does not have different types of (terrestrial) landscapes. The Municipality of Žužemberk is much larger than the rest of these municipalities, but because it is located in Dinaric plateaus, which are not diverse, it does not have many different types of relief, vegetation, or rocks.

Table 1: Average landscape diversity coefficient for landscape types and landscape type combinations, including municipalities with the highest average landscape diversity coefficient within each landscape type and each landscape type combination.

\begin{tabular}{|c|c|c|c|c|c|c|}
\hline ID & $\begin{array}{l}\text { Landscape types and } \\
\text { landscape type combinations }\end{array}$ & $\begin{array}{r}\text { Area } \\
\left(\mathrm{km}^{2}\right)\end{array}$ & $\begin{array}{r}\text { Average } \\
\text { coefficient }\end{array}$ & $\begin{array}{l}\text { Number of } \\
\text { munici- } \\
\text { palities }\end{array}$ & $\begin{array}{r}\text { Municipality with the } \\
\text { highest average } \\
\text { coefficient }\end{array}$ & $\begin{array}{r}\text { Municipality } \\
\text { average } \\
\text { coefficient }\end{array}$ \\
\hline 1 & Alpine mountains & 3061 & 0.1836 & 11 & Nazarje & 0.2419 \\
\hline 2 & Alpine hills & 4660 & 0.1823 & 22 & Hrastnik & 0.2163 \\
\hline 3 & Alpine plains & 819 & 0.1744 & 4 & Trzin & 0.2116 \\
\hline 4 & Pannonian hills & 2993 & 0.1544 & 25 & Poljčane & 0.1849 \\
\hline 5 & Pannonian plains & 1296 & 0.1436 & 9 & Tišina & 0.1263 \\
\hline 6 & Dinaric plateaus & 3809 & 0.1442 & 5 & Kostel & 0.1643 \\
\hline 7 & Dinaric plains & 1897 & 0.1546 & 0 & - & - \\
\hline 8 & Mediterranean hills & 1061 & 0.1493 & 4 & Šempeter-Vrtojba & 0.1727 \\
\hline 9 & Mediterranean plateaus & 673 & 0.129 & 0 & - & - \\
\hline $1-2$ & Alpine mountains and hills & 7721 & 0.1828 & 10 & Mozirje & 0.2230 \\
\hline $1-3$ & Alpine mountains and plains & 3880 & 0.1817 & 8 & Žirovnica & 0.2036 \\
\hline $2-3$ & Alpine hills and plains & 5479 & 0.1812 & 11 & Polzela & 0.2133 \\
\hline $2-4$ & Alpine hills, Pannonian hills & 7653 & 0.1714 & 12 & Store & 0.2286 \\
\hline $2-5$ & Alpine hills, Pannonian plains & 5956 & 0.1739 & 2 & Hoče-Slivnica & 0.1521 \\
\hline $2-6$ & Alpine hills, Dinaric plateaus & 8469 & 0.1652 & 1 & Šentrupert & 0.1616 \\
\hline $2-7$ & Alpine hills, Dinaric plains & 6557 & 0.1743 & 2 & Log-Dragomer & 0.2117 \\
\hline $4-5$ & Pannonian hills and plains & 4289 & 0.1512 & 28 & Gornja Radgona & 0.1670 \\
\hline
\end{tabular}




\begin{tabular}{|c|c|c|c|c|c|c|}
\hline $5-6$ & Pannonian plains, Dinaric plateaus & 5105 & 0.1441 & 1 & Kostanjevica na Krki & 0.1717 \\
\hline $6-7$ & Dinaric plateaus and plains & 5706 & 0.1477 & 15 & Borovnica & 0.1831 \\
\hline $6-8$ & Dinaric plateaus, Mediterranean hills & 4870 & 0.1453 & 2 & Vipava & 0.1546 \\
\hline $8-9$ & Mediterranean hills and plateaus & 1734 & 0.1415 & 6 & Renče-Vogrsko & 0.1673 \\
\hline $1-2-3$ & Alpine mountains, hills and plains & 8540 & 0.1820 & 6 & Vransko & 0.2194 \\
\hline $1-2-6$ & $\begin{array}{l}\text { Alpine mountains and hills, Dinaric } \\
\text { plateaus }\end{array}$ & 11530 & 0.1701 & 2 & Tolmin & 0.1952 \\
\hline $2-3-4$ & Alpine hills and plains, Pannonian hills & 8472 & 0.1717 & 1 & Vojnik & 0.2039 \\
\hline $2-3-7$ & Alpine hills and plains, Dinaric plains & 7376 & 0.1743 & 1 & Ljubljana & 0.1546 \\
\hline $2-4-5$ & Alpine hills, Pannonian hills and plains & 8949 & 0.1674 & 2 & Maribor & 0.1631 \\
\hline $2-4-6$ & $\begin{array}{l}\text { Alpine hills, Pannonian hills, Dinaric } \\
\text { plateaus }\end{array}$ & 11462 & 0.1624 & 1 & Mokronog-Trebelno & 0.1704 \\
\hline $2-6-7$ & Alpine hills, Dinaric plateaus and plains & 10366 & 0.1633 & 9 & Škofljica & 0.1968 \\
\hline $5-6-7$ & $\begin{array}{l}\text { Pannonian plains, Dinaric plateaus and } \\
\text { plains }\end{array}$ & 7002 & 0.1469 & 1 & Šentjernej & 0.1716 \\
\hline $6-7-8$ & $\begin{array}{l}\text { Dinaric plateaus and plains, } \\
\text { Mediterranean hills }\end{array}$ & 6766 & 0.1479 & 2 & Postojna & 0.1514 \\
\hline $6-8-9$ & $\begin{array}{l}\text { Dinaric plateaus, Mediterranean hills } \\
\text { and plateaus }\end{array}$ & 5543 & 0.1434 & 2 & Ajdovščina & 0.1596 \\
\hline $7-8-9$ & $\begin{array}{l}\text { Dinaric plains,Mediterranean hills and } \\
\text { plateaus }\end{array}$ & 3630 & 0.1484 & 1 & Divača & 0.1426 \\
\hline $2-4-5-6$ & $\begin{array}{l}\text { Alpine hills, Pannonian hills and plains, } \\
\text { Dinaric plateaus }\end{array}$ & 12758 & 0.1605 & 2 & Brežice & 0.1831 \\
\hline $4-5-6-7$ & $\begin{array}{l}\text { Pannonian hills and plains, Dinaric } \\
\text { plateaus and plains }\end{array}$ & 9995 & 0.1492 & 2 & Šmarješke Toplice & 0.1905 \\
\hline \multirow[t]{3}{*}{$6-7-8-9$} & $\begin{array}{l}\text { Dinaric plateaus and } \\
\text { plains,Mediterranean hills and plateaus }\end{array}$ & 7440 & 0.1463 & 1 & Ilirska Bistrica & 0.1378 \\
\hline & & & & & & 0.1704 \\
\hline & Slovenia & 20273 & 0.1624 & 211 & Nazarje & 0.2419 \\
\hline
\end{tabular}

\section{DISCUSSION AND CONCLUSION}

The article analyzed landscape diversity in Slovenia based on relief, rocks, and vegetation. It presented the most diverse municipalities in Slovenia and also the least. Among all the municipalities, the Alpine Municipality of Nazarje has the maximum landscape diversity coefficient, at 0.2419 , whereas the Pannonian municipality of Markovci in northeastern Slovenia has the smallest one, at 0.1045. Diversity may offer certain benefits, such as higher tourist visits due to the presence of varied natural phenomena, but on the other hand such municipalities may face various natural hazards. Diversity also prevents the simple transfer of good practices from one part of the municipality to another.

The results offer a basis for a more detailed analysis. An evaluation based on current data, field research, and expert assessment can further define the role of natural landscape diversity for the risk of natural hazards. This can also be analyzed in relation to settlement patterns (i.e., spatial planning), development of agriculture and tourism, and the overall economy. In such a way, it is possible to assess the actual influence of landscape diversity on society. Namely, the proper application of landscape pattern analysis is not trivial [4]. Although biodiversity is usually considered at the species level, maintenance of biodiversity requires management at higher levels of organization, particularly at the landscape scale [3]. Thus we believe such analyses are important and useful for our community. 


\section{Acknowledgement}

The authors acknowledge financial support from the Slovenian Research Agency and the Slovenian Academy of Sciences and Arts (project no. L6-6852: Landscape Diversity and Hotspots of Slovenia).

\section{REFERENCES}

[1] Ciglič, R. \& Perko, D. Europe's landscape hotspots. Acta geographica Slovenica, Slovenia, vol. 53, pp 117-139, 2013.

[2] Li, H. \& Reynolds, J. F. On definition and quantification of heterogeneity. Oikos, Denmark, vol. 73, pp 280-284, 1995.

[3] Peters, D. P. C. \& Goslee, S. C. Landscape diversity. Encyclopedia of biodiversity, USA, vol. 3, pp 645-658, 2001.

[4] Gustafson, E. J. Quantifying landscape spatial pattern: What is the state of the art? Ecosystems, USA, vol. 1, pp 143-156, 1998.

[5] Romme,W. H. Fire and landscape diversity in subalpine forests of Yellowstone national park. Ecological monographs, USA, vol. 52, pp 199-221, 1982.

[6] McGarigal, K. \& Marks, B. J. FRAGSTATS: Spatial pattern analysis program for quantifying landscape structure. USA, pp 1-141, 1994.

[7] Perko, D., Hrvatin, M. \& Ciglič, R. A methodology for natural landscape typification of Slovenia. Acta geographica Slovenica, Slovenia, vol. 55, pp 235-270, 2015.

[8] Digitalni model višin z ločljivostjo (DMV 12,5, DMV 25, DMV 100), 2014. URL: http://www.e-

prostor.gov.si/si/zbirke_prostorskih_podatkov/topografski_in_kartografski_podatki/digi talni_model_visin/digitalni_model_visin_z_locljivostjo_dmv_125_dmv_25_dmv_100/ (1. 3. 2014).

[9] Perko, D. The Regionalization of Slovenia. Acta geographica, Slovenia, vol. 38, pp 11-57, 1998. 